\title{
Towards a generic framework for the development of logistics in seaports: lessons from the Busan case
}

\author{
Christophe Theys ${ }^{*}$, Dong Keun Ryoo ${ }^{* *}$ and Theo Notteboom ${ }^{* * *}$
}

\begin{abstract}
This paper presents a generic framework on port logistics development and its interaction with hinterland regions. Although earlier work on the topic (e.g. by Ferrari et al., 2006; Kuipers and Eenhuizen, 2004) offers valuable insights in the subject, it contains limitations in geographical applicability. Ports indeed face dissimilarities in, for instance, locational characteristics (a.o. distance from the sea and nautical accessibility) and hinterland connections. Only when a model for determining seaport-located logistics activities takes into account these issues of dissimilarity among ports, the framework could be applied to a variety of seaport ranges worldwide. In this paper we aim to provide a first version of such a framework. More particularly, by means of a survey conducted in the Port of Busan the shortcomings of traditional approaches are illustrated. We then propose a more encompassing model, which seems to explain fairly well the attractiveness of Busan in terms of logistics activities. This framework explicitly adds port and hinterland characteristics to the list of factors decisive in the choice of the location of logistics activities. Finally, we would like to remark that our research on this topic is still ongoing and results for surveys planned in New York and Antwerp will be reported in a later stage.
\end{abstract}

Keywords: port-based logistics, hinterland interaction, generic framework, case study, Busan

Submission Date: 09/07/2008 Revision Date: 06/10/2008 Acceptance Date: 10/12/2008

"Corresponding Author, FWO Research Fellow , ITMMA - University of Antwerp, Keizerstraat 64, 2000 Antwerp, Belgium. Tel: +32 3 275.51.55, Fax: +32 3 275.51.50, E-mail: christophe.theys@ua.ac.be

** Professor, Korea Maritime University College of International Studies, Division of Shipping Management \#1 Dongsamdong, Youngdo-gu, Busan, Korea 606-791. Tel : +82 (0)51 410 4381, Fax : +82 (0)51 405-0233, dkryoo@hhu.ac.kr

${ }^{*}$ Pret PresidentProfessor ITMMA - University of Antwerp, Keizerstraat 64, 2000 Antwerp, Belgium. Tel: +32 3 275.51.52, Fax:+323 275.51.50, E-mail: theo.notteboom@ua.ac.be 


\section{Introduction}

Current trends of increased globalization and delocalization of production facilities further spur the growth in container traffic and are expected to continue doing so in the future. The considerable importance of flexible and responsive, yet at the same time cost-efficient logistics networks for local, regional or even global distribution of goods produced elsewhere, thereby becomes prevalent. With development plans in seaports and their hinterlands, however, it remains to be seen where future logistics activities will be ideally located.

This paper presents a global framework on port logistics development and its interaction with hinterland regions. Earlier work on the topic has been done by Ferrari et al. (2006) and Kuipers and Eenhuizen (2004). The former looked into the spatial distribution of European Distribution Centers in Southern European ports, while the latter developed a conceptual framework for the location analysis of (port-related) logistics activities. Although both papers offer valuable insights in the subject, they contain limitations in their geographical applicability. Ports face, after all, dissimilarities in locational characteristics (a.o. distance from the sea, hinterland connections), competitive environment (a.o. shipper-carrier interaction) or development phase (e.g. Bird, 1980; Notteboom and Rodrigue, 2005). It is the aim of the current paper to go beyond the limitations of existing research on the topic and to develop a more region-independent framework on port logistics in which especially port location and hinterland development factors will be included.

\section{The changing logistics environment}

Logistics models evolve continuously as a result of influences and factors such as the globalization and expansion into new markets, mass customization in response to product and market segmentation, lean manufacturing practices and associated shifts in costs. Service expectations of customers are moving towards a push for higher flexibility, reliability and precision. There is a growing demand from the customer for 'make-to-order' or 'customized' products, delivered at maximum speed, with supreme delivery reliability, at the lowest possible cost. The focus is on supply chain excellence, with superior customer service and lowest cost to serve.

As a result international supply chains have become complex and the pressure on the logistics industry is increasing. Leading-edge companies are taking a broader view of the parts of their business they seek to control and manage. Increasing customer demands drive the 3PL service industry (Third Party Logistics) forward. Customers' need for a wider array of global services at the same time opened the market to innovative forms of non-asset based logistics service provision, i.e. 4PL (Fourth Party Logistics). Whereas a 3PL service provider typically invests in warehouses and transport material, a 4PL service provider restricts its scope to IT-based supply chain design.

Consolidation and vertical integration strategies have created a logistics market consisting of a wide variety of service providers ranging from megacarriers to local niche operators. Not only the geographic coverage of the players differs (from global to local). Major differences can also be 
observed in the focus (generalist versus specialist), in the service offering (from single service to one-stop shop) and in asset-orientation (asset based versus non-asset based).

Supply chains are being redesigned to respond to varying customer and product service level requirements. When it comes to distribution of overseas goods, a general distribution structure does not exist. Companies can opt for direct delivery without going through a distribution centre, distribution through a main distribution centre (MDC), distribution through a group of national or regional distribution centers (NDC and RDC) or a tiered structure in which one MDC and several $\mathrm{NDCs} / \mathrm{RDCs}$ are combined to form a distribution network. These structures can be complemented by 'merge in transit' concepts or 'cross docking' facilities to offer a high level of service, frequency of delivery and distribution cost control.

The variables which affect site selection are numerous and quite diverse and can be of a quantitative or qualitative nature, cf. centrality, accessibility, size of the market, track record regarding reputation/experience, land and its attributes, labor (costs, quality, productivity), capital (investment climate, bank environment), government policy and planning (subsidies, taxes) and personal factors and amenities. Logistics service providers have developed powerful tools to assist shippers in selecting an appropriate network configuration and in site selection.

Due to the increasing variety of products and shorter product life cycles, many companies have chosen to move their country and customer specific kitting or assembly operations as close to the customer as possible. This implied that the traditional storage and distribution functions of many distribution centers are supplemented by semi-industrial activities such as the 'customizing' and 'localizing' of products, adding components or manuals, product testing, quality control or even final assembly. These activities are referred to as value added logistics services (VAL). While setting up their logistics platforms, logistics service providers favor locations that combine a central location (i.e. proximity to the consumers market) with an intermodal gateway function. Seaports and sites along hinterland corridors typically meet these requirements.

\section{Logistics activities in ports and their hinterland}

\subsection{Towards a closer integration between seaports and inland ports?}

The dynamics in logistics networks have created the right conditions for a large-scale development of inland ports, mainly in Europe, North-America and parts of China (cf. Yangtze basin). The range of functions of inland logistics centers is wide ranging from simple cargo consolidation to advanced logistics services. Many inland locations with multimodal access have become broader logistics zones. They not only have assumed a significant number of traditional cargo handling functions and services, but also have attracted many related services, among others distribution centers, shipping agents, trucking companies, forwarders, container repair facilities and packing firms.

Quite a few of these logistics zones are competing with seaports for what the location of distribution facilities are concerned. Shortage of industrial premises, high land prices, congestion 
problems, the inland location of the European markets and severe environmental restrictions are some of the well-known arguments for companies not to locate in a seaport. The availability of fast, efficient and reliable intermodal connections is one of the most important prerequisites for the further development of inland terminals (e.g. Woxenius et al., 2004; Van Klink and Van den Berg, 1998). The interaction between seaports and inland locations leads to the development of a large logistics pole consisting of several logistics zones. Seaports are the central nodes driving the dynamics in such a large logistics pole. But at the same time seaports rely heavily on inland ports to preserve their attractiveness (Notteboom and Winkelmans, 2004).

The emergence of large logistics poles poses new challenges in the relations between ports and inland ports. With the creation of logistics poles, port benefits might leak to users in inland locations. An active port regionalization strategy (Notteboom and Rodrigue, 2005) makes it possible to benefit the most from the reshaped networking among nodes. Ports have to fully benefit from synergies with other transport nodes and other players within the networks of which they are part. This supports the development of a broader regional load centre network, serving the large logistics poles. At the same time, the corridors towards the inland terminal network can create the necessary margin for further growth of seaborne container traffic in the port. Inland terminals as such acquire an important satellite function with respect to ports, as they can help to relieve the seaport area from potential congestion.

\subsection{Is there still a role for ports as habitats for logistics activities?}

Notwithstanding the rise of inland ports in many parts of the world, seaports typically remain key constituents of many supply chains. Many ports have actively stimulated logistics polarization in port areas through the enhancement of flexible labor conditions, smooth customs formalities (in combination with freeport status) and powerful information systems.

Logistics activities can take place on the terminal itself, in a logistics park where several logistics activities are concentrated or in case of industrial subcontracting on the site of an industrial company. While there is a clear tendency in the container sector to move away from the terminal, in other cargo categories an expansion of logistics on the terminals itself can be witnessed. As such, a mix of pure stevedoring activities and logistics activities occurs.

Many seaports have responded by creating logistics parks inside the port area or in the immediate vicinity of the port. The concentration of logistics companies in dedicated logistics parks offers more advantages than providing small and separated complexes. Five basic types of port-based logistics parks can be distinguished (Buck Consultants International, 1996; Kuipers, 1999):

- Traditional seaport-based logistics park: this type of logistics park is associated with the pre-container area in seaports.

- Container oriented logistics parks. This is the dominant type with a number of large warehouses close to the container terminal locations and intermodal terminal facilities.

- Specialised seaport-based logistics parks. This type of park specializes on different functions, often closely related to the characteristics of the seaport. The park may focus on 
the storage of liquid bulk (chemicals), on trade in which a combination of warehousing and office space is offered to a number of import-export companies from developing countries or on high-value office-related employment in which Fourth Party Logistics Service Providers, logistics software firms, financial service providers to the maritime industry and consultants are located in the park.

- Peripheral seaport-based logistics parks. These parks are located just outside the port area which typically offers advantages with respect to congestion, costs of land and labor. These peripheral parks are part of the greater seaport region and may benefit from suppliers and other specialized inputs associated with the seaports.

- Virtual port-based logistics parks. These parks are located outside the greater seaport area, sometimes at a distance of more than a hundred kilometers from the seaport itself, but have a clear orientation to one or more seaports with respect to the origins of the (containerized) cargo.

The term 'virtual' is associated with a process called 'virtual subharborization', the rise of port-based activities in the hinterland of the ports together with a stagnation of these activities in the ports itself. Distribution centers are the main example of this activity (Buck Consultants International, 1996). The process of virtual subharborization is closely linked to the creation of large logistics poles.

As the hinterland becomes a competitive location, the question remains as to which logistics activities are truly port-related. In the new logistic market environment, the following logistics activities typically find a good habitat in ports (Derveaux, 2004):

- Logistics activities resulting in a considerable reduction in the transported volume

- Logistics activities involving big volumes of bulk cargoes, suitable for inland navigation and rail

- Logistics activities directly related to companies which have a site in the port area

- Logistics activities related to cargo that needs flexible storage to create a buffer (products subject to season dependent fluctuations or irregular supply)

- Logistics activities with a high dependency on short-sea shipping

Moreover, port areas typically possess a strong competitiveness for distribution centers in a multiple import structure and as a consolidation centre for export cargo.

Along the same lines, Kuipers and Eenhuizen (2004) identified a set of important logistics characteristics that can have an impact on the choice of distribution structures and on whether or not to locate logistics/distribution activities in a port:

- The value-density expressed in value per cubic meter

- The delivery frequency

- Economies of scale and scope in production

- Country-specific product or packaging requirements

- Distribution focus measured in service requirements, instead of low costs 
- Share of transport costs in total distribution costs

- Share of distribution costs in total production costs

- Technological dynamism related to the product

\subsection{A classification of ports based on their logistics focus: beyond existing research}

Not all ports follow the same path in developing logistics activities. The conceptual model of port development from the United Nations (2005), adapted from the work of Valentine and Gray (2000), starts from the idea that ports which previously focused on import/export cargo could benefit from a (partial) move into more transshipment on the one hand, or from profiling themselves as a logistics centre port on the other hand (Figure 1). Those ports located closely to major shipping routes will have more potential to attract the cargoes necessary to become a transshipment hub, while ports nearby major markets in the hinterland would better invest in the development of logistics centres. Research of Frankel (1987) and the United Nations (2002), for instance, illustrated that the benefits of value creation in such logistics centers should not be underestimated (e.g. for import cargo up to $50 \%$ to $80 \%$ of the cargo value).

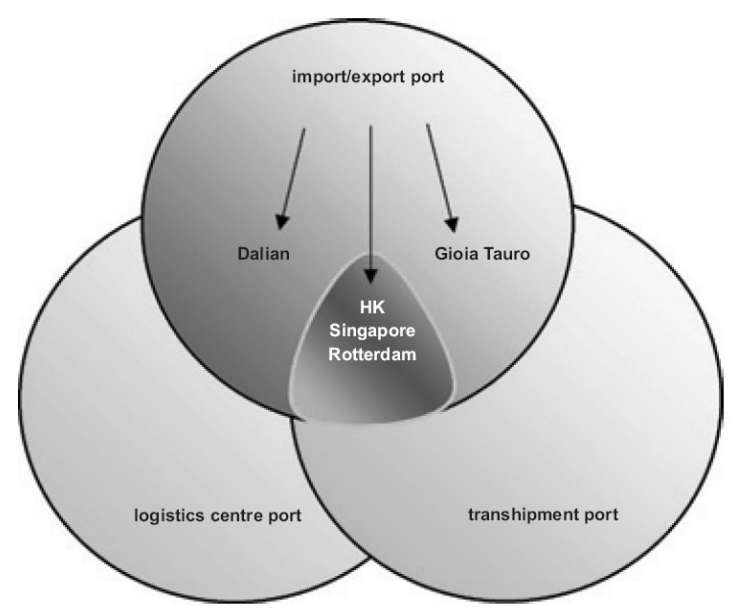

Source: United Nations (2005)

Figure 1. Conceptual model of port development

While ports in the United Nations (2005) port development model could focus on either attracting transshipment cargo or on developing logistics centers, the model rightfully states that certain ports, such as Hong Kong, Singapore and Rotterdam, benefit from a favorable position combining both courses of action. Several of the characteristics of those latter ports, however, are different. This makes it hard to justify a conceptual model in which no distinction among the particular features of each of these ports is made. The miscalculation of the model, in our opinion, 
lies in the fact that one considers the road towards becoming a logistics centre as one of three alternative strategies (but not necessarily mutually exclusive), with the focus on import/export cargo and transshipment as the two other possibilities. Better would be to acknowledge that on the one hand ports can serve import/export cargo or transshipment (or both), while on the other hand they might or might not be engaged in each of those cargo types in logistics solutions and valueadding activities. This allows for a better categorization of ports.

While, for instance, the ports of Rotterdam and Singapore both offer value-added logistics and services, the cargoes on which they perform these activities are fundamentally different. Singapore is strongly focused on transshipment cargo and will use its distriparks mainly to offer logistics solutions to transshipment cargo and smaller local flows. Rotterdam also has transshipment cargo, but its main focus is still on import and (to a lesser extent) export cargo, destined for or coming from the European hinterland (i.e. gateway traffic). Therefore, distriparks here are mainly focused on the import/export cargo types. In certain specific cases, however, such as for the distribution center of Reebok at the Maasvlakte Distripark, logistics centers are also dealing with transshipment cargo, but to a much lesser extent than in Singapore. Yet another port, Antwerp, is mainly exportfocused, although it also deals with transshipment cargo originating from the North-European hub of Mediterranean Shipping Company at the Delwaide Dock. Nevertheless, no major value-adding logistics activities are performed on these transshipment cargoes.

From the above it already becomes clear that from a theoretical point of view more research into ports' attractiveness for locating logistics activities is useful, especially taking into account functional and spatial differences that exist among seaports worldwide. In the next section we will illustrate that empirical evidence also justifies more thorough research into the function of ports in logistics structures.

\section{Empirical research on port logistics activities in Busan}

In order to analyze the influence of geographic, economic and cultural differences on the logistics potential of ports a questionnaire was developed and presented to captains of industry in major ports. Each respondent was asked to rate the importance of a set of factors for attracting logistics in port areas, in order to determine under which (generalized) conditions future logistics activities will be located in seaports and when logistics parks in hinterland regions will be preferred. The answers to the 101 questions of the questionnaire were expressed on a five-point Likert scale.

The survey was divided into three parts. In the first part companies where asked to which extent they agree with a number of statements on the port in which they operate. The purpose of this part was to observe distinct answer patterns among respondents in different seaports, as well as to better characterize the seaports in which these respondents operate. The second part of the questionnaire then concerned factors that might be decisive when considering the location of logistics activities in the port or the hinterland region. Here we not only asked for product and firm characteristics, but also included port characteristics. The latter both contained elements immediately related to ports and factors more concerning the port's hinterland. In the third part of the survey, 
then, we no longer focused on the potential of a seaport in locating logistics activities, but on the actual performance of the port under consideration.

The questionnaire was intentionally kept globally applicable, since from the start the idea was to compare answer patterns from respondents in seaports at different continents. This paper reports on the results obtained from 47 responses on surveys sent out in the Port of Busan (South-Korea). In the Port of Antwerp (Belgium) and the Ports of New York and New Jersey (USA) the study is ongoing. While the intention of the final study is to quantitatively analyze the Likert responses using non-parametrical statistical tests we will restrict the scope of this paper to a qualitative discussion of the influence of port, firm and product characteristics on the logistics attractiveness of ports. The choice for a qualitative discussion is linked to the limited number of observations for the Busan surey. For certain issues the general opinion of the respondents in Busan diverted substantially from what is commonly claimed in existing port logistics frameworks for European ports. These empirical observations led to a new conceptual framework, which will be presented in Section 5. First, however, we will discuss the test results in Busan.

\subsection{Port of Busan}

A large part of the 47 million inhabitants of South-Korea lives in the cities of Seoul and Busan, located at opposite ends of the country, respectively in the North and the South. Both cities have a considerable population density of several thousands of citizens per square kilometer and form an axis of industrial activity including the cities of Daegu and Daejeon (see Figure 2).

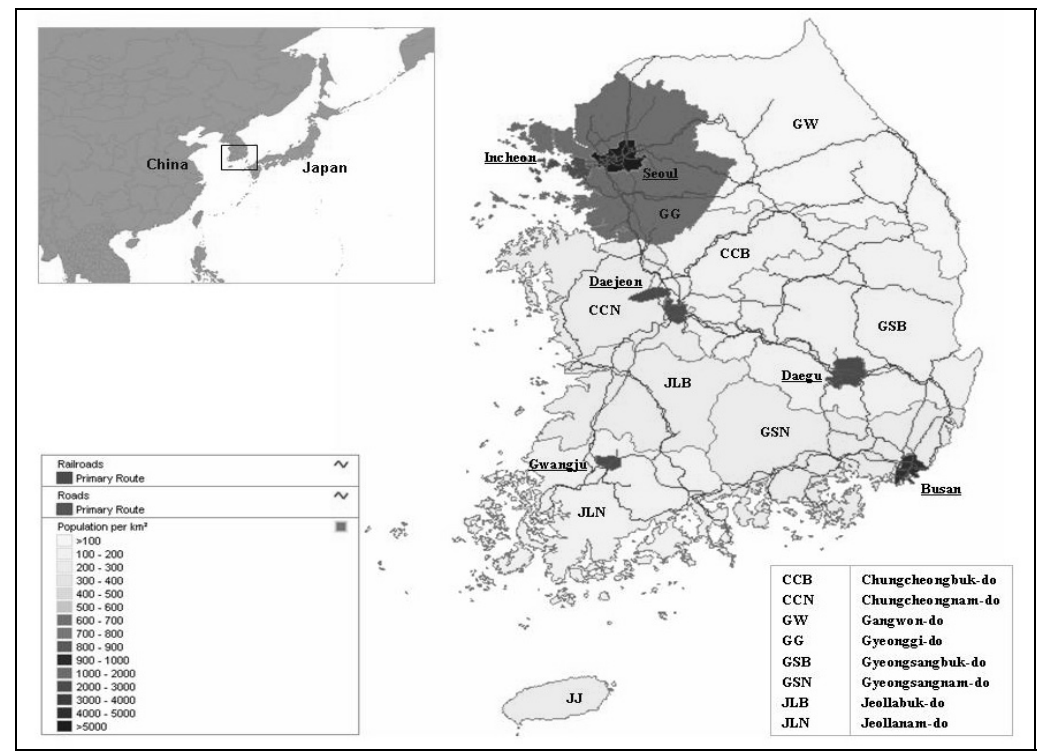

Source: Own representation

Figure 2. Main industrial areas and transportation axes in South-Korea 
From a transportation perspective South-Korea is characterized by considerable traffic flows on the industrial axis Busan-Seoul, on which one finds the main roads and railroads. A second North-South axis is located to the West of Busan and connects Seoul with the region surrounding Gwangju. From Daejeon onwards this second axis merges with the axis originating in Busan. Regarding sea-based transportation, the country has a fairly large number of seaports, but the Port of Busan is responsible for most of the container throughput. In 2005 Busan handled more than $77 \%$ of total Korean container throughput, which was considerably more than Gwangyang (9.5\%), Incheon (7.5\%), Ulsan (2\%) and Pyoungtaek $(<1.5 \%)$. Ports as Masan, Yeocheon and Gunsan, finally, contributed each for less than $0.5 \%$ to the total Korean container throughput. In terms of modal split road transportation is predominantly favoured, constituting in $200588.4 \%$ of total cargo to and from the Port of Busan. Rail transportation could attract some $10.3 \%$ of the cargo, but short sea shipping is with $1.3 \%$ far less used in dispersing the cargo from its main port towards the Korean hinterland (Busan Port Authority). Inland navigation, last but not least, is so far nearly inexistent, but the use of this mode is currently under investigation.

Around eighty percent of the total throughput in the Port of Busan is containerized conventional cargo. Figure 3 illustrates that annual throughput in this product market has grown considerably between 1993 and 2006, from roughly three million TEU to over twelve million. In recent years transshipment has become of utmost importance for Busan and has grown faster than import and export cargo destined for the local markets. For the latter the average annual growth rates over the considered period were some eight respectively six percent, while transshipment cargoes between 1993 and 2006 on average grew with 26 percent per year. This evidently caused major changes in the transshipment share from 8.5 percent in 1993 to more than 43 percent in 2006. Busan's favorable location at the intersection of major trade routes was undoubtedly a strong stimulus for transshipment in the Korean port.

From an operational point of view the Port of Busan is subdivided into an older port area which is still most frequently used and the partially developed new port area in the so-called Busan New Port. Busan also has a large port logistics industry, which in 2004 employed nearly 93 thousand people in more than 18 thousand companies. Over ten thousand of these companies were involved in transportation activities, of which approximately $97 \%$ was focused on road transportation. Additionally, some 360 companies were involved in materials handling and 55 in packaging. Warehousing counted around 240 companies, with general and bonded warehousing as most important categories (each nearly one third of the total), together with refrigerated storage (one fourth). Other business in the port included 3800 service companies under which forwarders and agents and some 3400 companies involved in manufacturing of transport-relevant goods (Busan Metropolitan City). 


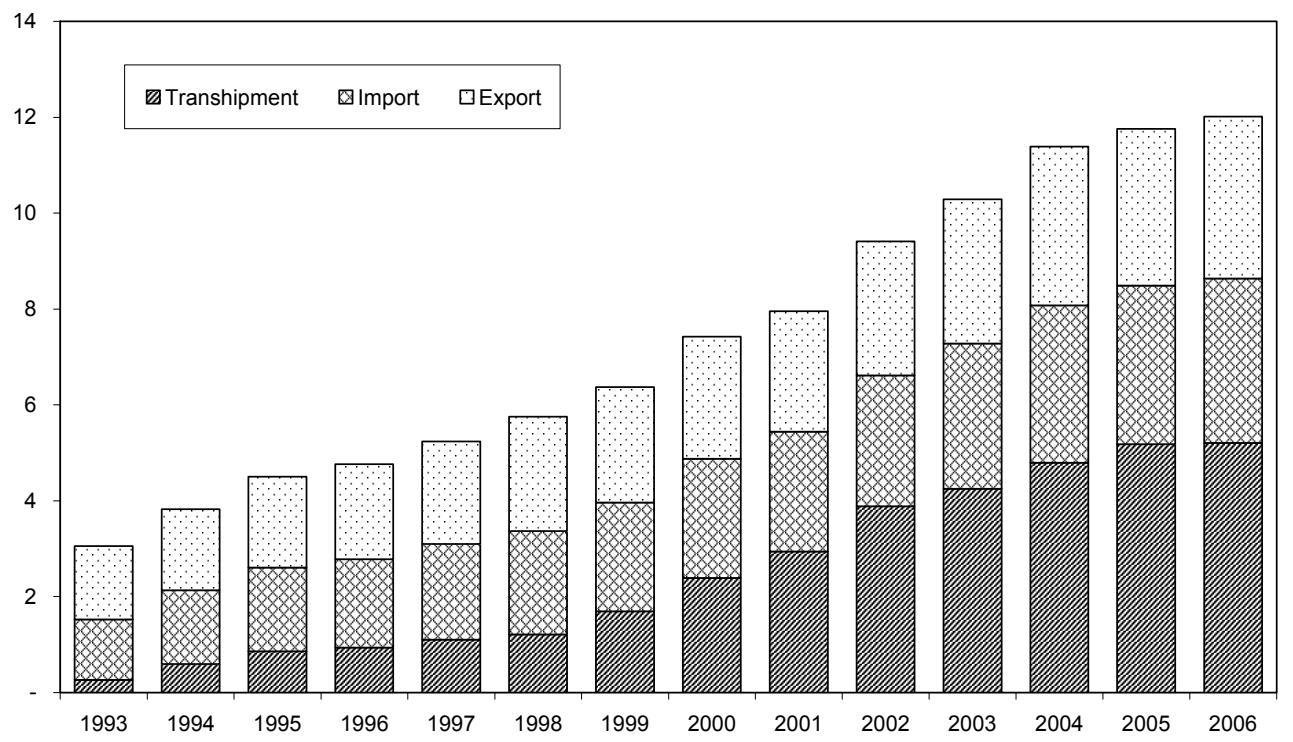

Source: Busan Port Authority

Figure 3. Container throughput in Busan (million TEU)

\subsection{Empirical findings on port characteristics}

In terms of port characteristics 31 statements were created, including nautical, geographical, economic, cultural and policy-related issues. Important to recall is that those statements both comprised purely port-related factors as factors linked to hinterland development. In general, respondents in the Port of Busan acknowledged that port characteristics play a role when choosing among port or hinterland area for locating logistics activities, but not all characteristics are of equal importance.

Characteristics related to a port's geographical location, size and production factors are generally considered important by companies in Busan in deciding between port and hinterland in locating logistics activities. One of the most contributing factors to the logistics attractiveness of a port is, according to the responses, its geographical location near main shipping routes. Similarly, in the opinion of players in the Busan region the more a port is accessible to larger container vessels (5000 TEU and more) the more interesting it will be for developing logistics activities, as compared to hinterland areas. Good availability and high quality of both modern port infrastructure and superstructure also enhance a port's logistics position relative to the hinterland, just as a high level of technological innovation in the port. The latter could be achieved, for instance, through the integration of ICT systems or through automation. When sufficiently available, companies in Busan declare yet another production factor - port labor - advantageous to a port's logistics attractiveness, just like the operational skills of the port society. It also appeared that a larger scale and more throughput make a port more attractive for logistics, and so was the close location of 
logistics zones to container terminals and other infrastructure. Although the importance of certain of the aforementioned factors could be intuitively explained for many seaports, the particularly strong link between the shipping industry and logistics activities caught our attention.

Furthermore, at first sight surprisingly was the fact that respondents in Busan did not consider the number and frequency of port-hinterland connections by road, rail, barge or pipeline among those factors most influencing a port's logistics attractiveness. The close proximity of ports to major consumptions areas and a location near other seaports, however, were thought to contribute more to a port's logistics attractiveness, but the proximity of the port to production and consumption centers in the own hinterland is less important. Perhaps rather culturally influenced, finally, market players in Busan generally add less weight to the multicultural character of the port and language knowledge of port society when it comes to determining logistics attractiveness of ports. Although hard to quantify and analyze, port reputation and port image, on the other hand, were considered quite influential to logistics attractiveness.

Since certain of the above-mentioned results such as the strong focus on maritime port characteristics and the smaller importance of hinterland aspects deviate from what one might expect from, for instance, North-European port-hinterland interactions, we see a first motivation to continue with the development of a more generic framework on the role of ports in logistics structures.

\subsection{Empirical findings on firm characteristics}

The market players in the Port of Busan were questioned on 21 statements related to the influence of firm characteristics on the attractiveness of a port as a location for logistics activities. A port appears to be especially interesting for locating logistics activities for companies wishing to exploit large logistics facilities, as well as for firms with large annual cargo volumes or a large share of exporting and re-exporting activities. Furthermore, firms with an integrated logistics network in which the distribution centre is part of a larger whole are highly likely to benefit more from locating in a port than companies with stand-alone distribution facilities. So are firms with a global service focus and to a slightly lesser extent a regional focus, as opposed to companies that act more locally. Additionally, respondents indicate that a port becomes more interesting for locating logistics facilities when a firm wishes to deploy common-user logistics facilities versus dedicated infrastructure.

Particularly interesting was also that the port was considered to have opportunities especially for companies with Value-Added Logistics and Services such as packaging, labeling, quality control and inventory management. When faced to high uncertainty in lead times or customer demand, however, the port is less appropriate than hinterland regions close to customer or production centers. On the other hand, for firms with a logistics strategy focused rather on cost reduction than service excellence and for companies with a stronger market power towards their customers the port is relatively attractive. In general, thus, for the Port of Busan the observations on the influence of firm characteristics on the logistics attractiveness of the port correspond fairly well to the research results of other studies (e.g. Kuipers and Eenhuizen, 2004; TNO Inro, 2004). 


\subsection{Empirical findings on product characteristics}

Finally, the market players in the Port of Busan were presented eight statements concerning product characteristics and asked to indicate how attractive a port is compared to the hinterland for locating logistics activities for products with these characteristics. Results here were most surprising. Of all products in the questionnaire companies in Busan considered those with a high delivery frequency and high share of distribution costs in the total production costs to be the products for which the port is most attractive. Furthermore, while we originally expected respondents to rate the port's logistics attractiveness for products with a high value per cubic meter or country-specific product and packaging requirements as low to very low, companies on average actually attributed a somewhat higher than medium attractiveness to those factors. The same holds to a lesser extent for products with a high technological dynamism and thus short product life cycles.

This, again, is not in line with what we initially would expect based upon knowledge of North-European ports. We hope to provide a satisfying explanation with the framework that will be described later on in this paper. Finally, we still witnessed similarities with mainstream thinking in Europe on port-logistics interaction when it came to products with high economies of scale and scope in production. For those products, as we expected, the port area remained the favorite location for companies.

\subsection{Performance evaluation of Busan}

Interestingly, we found a rather strong correlation between the weights that companies in Busan gave to each of the port characteristics and Busan's actual performance as evaluated by the market players (see Figure 4, with abbreviations in the Appendices). Generally, the Port of Busan performs relatively well on those factors considered most important in attracting logistics activities to the port area, while performance is less good when it comes to factors of lower importance. Depending on whether one considers the glass half full or half empty this can be explained by the Port Authority's successful efforts in attracting logistics activities or by the market players' loyalty to their port. Nevertheless, these results indicate that market players strongly believe in Busan's future as a location for logistics activities. In other words, they see market potential in locating logistics activities in the port area, whereas in other ports sometimes a more negative feeling with regards to the port's logistics attractiveness seems to be present. 


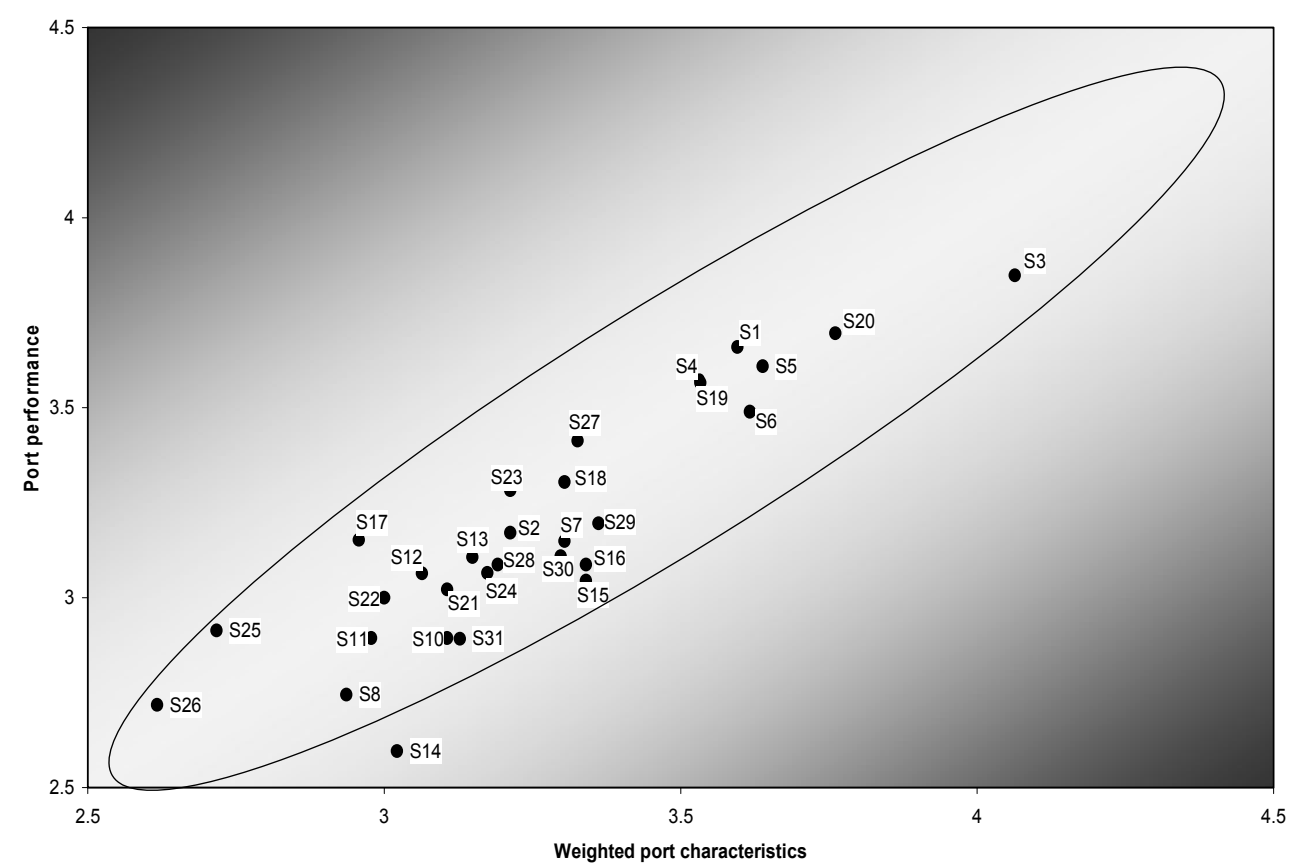

Figure 4. Port performance-weighted port characteristics matrix for Busan

\section{Towards a generic spatial typology of logistics in ports}

In the remainder of this paper we will develop a first empirical framework which intends to explain differences in ports when it comes to logistics attractiveness. The system starts from the premise that a port's logistics attractiveness is highly dependent on its particular characteristics, both purely port-related as in relation to the hinterland. It should be remarked, however, that the framework will still be verified with the results obtained from questionnaires sent out in the ports of Antwerp and New York. The final aim will be to create a more generic spatial typology of logistics activities in ports, supported by quantitative, (non-parametric) statistical testing.

In the discussion in Section 1 ports were classified based on whether they excel in handling import/export cargo, transshipment or perhaps a combination of both. Although the Port of Antwerp, for instance, has transshipment cargo from the Mediterranean Shipping Company, its focus is mainly on import/export cargo for the large European hinterland markets, while Singapore can be characterized as a true transshipment hub. Other ports such as Busan, however, both serve their own hinterland area as well as overseas markets through considerable transshipment throughput. This classification and the economic and geographic factors that are lying at its basis will greatly influence a port's role and attractiveness in terms of logistics activities.

Figure 5 provides a typology of seaports and their logistics function based on specific port and 
hinterland characteristics. The framework predicts not so much where firms will or should locate their logistics facilities, but rather what they can do. As such port and hinterland characteristics take the role of "enablers" (or disablers) of the logistics development and attractiveness of a port in relation to its hinterland. Certain port and hinterland characteristics will thus be necessary conditions for the development of port logistics centers, but they might not be sufficient conditions. After all, as previous research has already indicated, product and firm characteristics will determine for specific products and logistics structures whether to choose for the immediate port area in locating logistics facilities, or for the hinterland. However, if the necessary "enablers" in terms of port and hinterland factors are not present, not much choice is to be made.

Port characteristics (represented on the Y-axis in Figure 5) first and foremost determine a port's potential in becoming a logistics hub. While certain ports mainly serve their own hinterland (see parts A and B in Figure 5), other ports are better located and equipped to attract large transshipment flows (see $\mathrm{E}$ and $\mathrm{F}$ in Figure 5). Yet other ports will be able to combine both import/export and transshipment ( $\mathrm{C}$ and $\mathrm{D}$ in Figure 5). Given the economic importance of valueadded activities to the port region, ports capable of handling large transshipment flows might stimulate the development of logistics activities targeted to serving cargoes destined to overseas markets. Evidently, for ports without much transshipment potential attracting such logistics businesses to the port area makes little sense. Both import/export and transshipment ports, however, might house logistics facilities for goods with a hinterland destination. The level of corridor development plays a fundamental role (see X-axis of Figure 5). When corridors are poorly developed the port often remains the sole alternative to set up logistics activities for large flows of cargo (B, D and F). In case of strongly developed corridors, then, firms have a choice in locating logistics activities in the port or its hinterland (A, C and E). Under such circumstances product and firm characteristics become of vital importance and will finally lead to the choice for port or hinterland.

For the Port of Busan the natural hinterland corresponds to the major cities of South-Korea and its countryside. As was discussed before, a large transportation axis with rail but especially road transportation stretches between Seoul and Busan, from Daejeon on branched into a second line towards Gwangju. Nevertheless, because of the limited role of railroads in freight transportation (road transportation accounts for little less than $90 \%$ of traffic) this corridor is not as strongly developed as those in Europe or the United States. Busan, however, does not only serve the Southern part of the Korean peninsula, but through transshipment also overseas markets. Some of those markets are transpacific, but closer to home one also finds important export transshipment destinations, such as Japan and parts of China (see Figure 6). For some of those markets the port saw potential in developing value-added logistics activities. Mitsui OSK, for instance, exploits a distribution centre destined for the overseas (Japanese) market in one of Busan's logistics areas (Busan Port Authority). The idea in such distribution structures is to strip incoming containers from major shipping routes, reconsolidate their cargo - whether or not after processing - and ship them to final destinations in large overseas consumer areas. We will now discuss the port and hinterland aspects that are fundamental in the framework of Figure 5. 


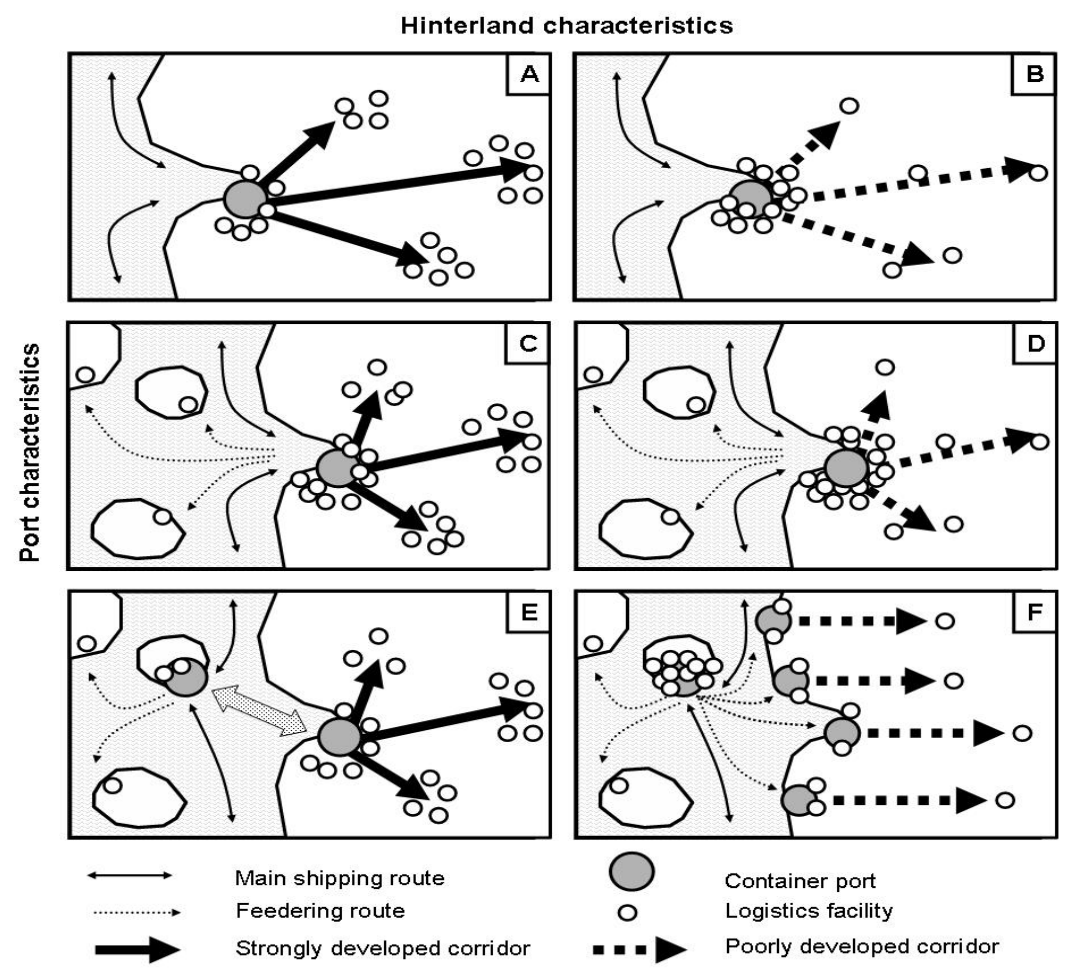

Figure 5. Location of logistics activities as a function of port and hinterland characteristics
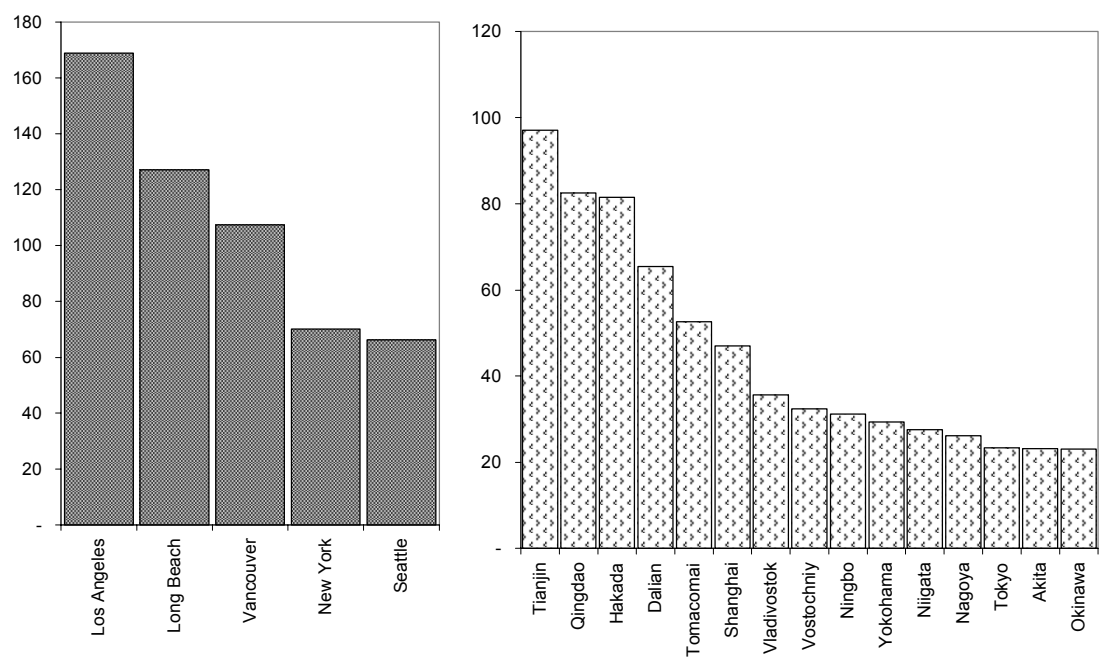

Source: Busan Port Authority (2006)

Figure 6. Export container transhipment from Busan to selected ports 


\subsection{Pure port characteristics}

When ports would like to engage in logistics activities (whether or not partially) targeted to transshipment cargoes the link between the maritime and logistics businesses comes more to the forefront (see parts $\mathrm{C}$ till E of Figure 5). Nautical accessibility, geographic location and a large port throughput will become of fundamental importance in attracting logistics activities to the port area. When the aim is to provide value-added logistics to transshipment cargo the port evidently has to be easily accessible to the majority of vessels, without stringent time windows or draft limitations. One could then use this competitive locational advantage to develop logistics activities and feedering services for cargoes destined to overseas areas of which the own ports are incapable of accommodating the larger vessels on a regular basis. In terms of nautical accessibility the Port of Busan benefits from its natural location close to the sea in a bay area, with drafts of up to 15-16 meters, allowing the port to handle cargo from even the largest container vessels (see Table 1).

Table 1

Draft of terminals in the Port of Busan

\begin{tabular}{c|c|c|c}
\hline Terminal & Draft & Terminal & Draft \\
\hline \hline Pusan Newport Corporation & $16 \mathrm{~m}$ & Sinsundae & $14 \mathrm{~m}$ \\
Jaseondae & $15 \mathrm{~m}$ & Gamcheon (Hanjin) & $13 \mathrm{~m}$ \\
Gamman & $15 \mathrm{~m}$ & Uam & $11 \mathrm{~m}$ \\
Singamman & $15 \mathrm{~m}$ & & \\
\hline
\end{tabular}

Equally important is the throughput of the port, which in combination with the number of port calls is not unlikely to create a snowball effect on cargo handled. Ports with high throughput and inclusion in important loops have much potential of becoming a logistics hub with value-added activities, from where cargo is dispersed using feedering services to smaller ports. This explains why market players in Busan considered the geographic location of the port and its proximity to major shipping routes as some of the most important characteristics favoring a port's logistics attractiveness as compared to the hinterland. The Port of Busan, as they stated, performs well on these port characteristics, as a result of its inclusion in 212 shipping loops, serving each of the continents including a large number of intra-Asia trades (see Table 2).

Given the considerable importance of maritime activities in the port logistics hub model the role of production factors related to cargo handling becomes clear as well. A good availability and high quality of modern port infrastructure and superstructure will favor these ports when it comes to attracting logistics facilities. This is because state-of-the-art equipment as well as a skilled and experienced labor force will ensure a quick and accurate cargo unloading, with minimal dwell times. Furthermore, investments in ICT systems will allow overseas shippers and receivers to stay updated on the progress of the logistics activities performed on their cargo. 


\subsection{Hinterland characteristics}

The importance for a port's logistics attractiveness of its proximity to major consumption areas located overseas has already been mentioned in the previous section and appeared to be especially relevant with regards to ports involved in value-added logistics for transshipment cargo. The size of production and consumption areas in the own hinterland is in fact the counterpart of this factor for ports focusing on import/export (A and B in Figure 5), or on both transshipment and import/export. Large service areas in a port's hinterland will attract more cargo through the port and hence give it the potential to develop logistics activities. Whether or not those activities finally will be located in the port area strongly depends on the extent to which corridors are developed. In case of poorly developed corridors logistics facilities will be mostly located in the vicinity of the port, while for strongly developed corridors those activities might shift to the hinterland. Notteboom and Rodrigue (2005) underlined that port regionalization and associated integrated hinterland networks promote the formation of discontinuous hinterlands. The service area of a container port by rail and barge takes the form of sets of overlapping service areas of individual inland terminals. By developing strong functional links with particular inland ports a seaport might intrude in the natural hinterland of competing ports. However, it also facilitates the move of logistics activities to hinterland locations and the emergency of logistics sites that use several gateway ports for incoming and outgoing flows instead of a single one.

Table 2

Liner services calling at Busan (per 28/01/2008)

\begin{tabular}{c|c|c|c|c|c|c|c}
\hline Service type & $\begin{array}{c}\text { Number of } \\
\text { services }\end{array}$ & FC & CB & BB & R & CBR & CR \\
\hline \hline Multi-trade & 15 & 13 & 2 & 0 & 0 & 0 & 0 \\
Asia-North-America & 31 & 28 & 3 & 0 & 0 & 0 & 0 \\
Europe-Asia & 33 & 26 & 5 & 2 & 0 & 0 & 0 \\
To/from South-and & 5 & 4 & 0 & 1 & 0 & 0 & 0 \\
East-Africa & 27 & 26 & 1 & 0 & 0 & 0 & 0 \\
To/from Caribbean and & 17 & 7 & 6 & 0 & 2 & 2 & 0 \\
South-America & 84 & 80 & 0 & 0 & 0 & 0 & 4 \\
To/from Australasia & 212 & 184 & 17 & 3 & 2 & 2 & 4 \\
Intra-Asia & 17 &
\end{tabular}

Remark: Services might call upon ports in other continents, but start and end is located in the continents under "type".

$\mathrm{FC}=$ Full Container service; $\mathrm{CB}=\mathrm{Con}-\mathrm{Bulk}$ service; $\mathrm{BB}=$ Break-Bulk service; $\mathrm{R}=$ Ro-Ro service;

$\mathrm{CBR}=$ Con-Bulk-Ro service; $\mathrm{CR}=\mathrm{Con}$-Ro service

Source: Own representation based on AXS-Alphaliner data 
Even when ports are involved in providing logistics services to transshipment cargo, hinterland characteristics remain of fundamental importance in terms of logistics attractiveness. First, if ports are serving both the own hinterland as overseas markets (parts C and D in Figure 5), the extent to which a corridor is developed will influence the number of logistics facilities in the port that serve the own hinterland markets. For poorly developed hinterland corridors, as is the case in part D of Figure 5, the port will be ideally located for logistics facilities targeted to the hinterland, on top of the logistics centers that were already based in the port area for serving overseas markets. In case of well-developed corridors, on the other hand, logistics facilities for import/export cargo might move closer to consumption and production areas in the hinterland. Second, the hinterland connections from (smaller) ports that are served by feedering connections (see parts $\mathrm{E}$ and $\mathrm{F}$ in Figure 5) also affect the location possibilities that companies have for logistics facilities. When a port transships cargo to smaller ports with poorly developed hinterland (part F of Figure 5), economies of scale and scope will make this port particularly attractive for locating logistics facilities targeted to those overseas areas. The overseas ports and their hinterlands will thus likely have relatively few logistics facilities. On the other hand, when the overseas port has a strongly developed corridor serving larger parts of its own hinterland (part E of Figure 6), that port actually reduces the logistics attractiveness of the port through which it is fed. Logistics facilities then will be located either in the area surrounding the overseas port, or in its hinterland. When over time cargo throughput in such ports increases, they might be directly served and hence evolve into the situation depicted in part A of Figure 6.

\subsection{The role of product and firm characteristics}

Previous research (e.g. Kuipers and Eenhuizen, 2004) concluded for ports more focused on import/export (see parts B and D of Figure 5) that logistics activities for products with a high delivery frequency are less likely to be located in the port area. Provided that corridors are sufficiently developed (B in Figure 5), this is true if the main geographic service areas of the port are located (deeper) in its continental hinterland. For logistics activities on transshipment cargoes to important service areas overseas (parts A and C in Figure 5), such as Japan and parts of China for the Port of Busan, these arguments no longer hold. Under these circumstances shippers of products with high delivery frequency and destined to such service areas will prefer to deploy logistics facilities within the port perimeter rather than in the hinterland. From there the overseas areas can be served faster and with higher frequency. Fundamental for the success of this port model, however, are the quantity and quality of short sea and feedering connections between the transshipment hub and the overseas service areas. Although a 24-hour service rule like described by Prologis-CapGemini (2006) for European distribution settings is probably exaggerated in the port hub logistics model, it is necessary to offer frequent and quick services to smaller ports that are unable to receive larger vessels because of nautical conditions or insufficient volumes. As is illustrated in Figure 7 for the Port of Busan, even the choice of vessels used on these service loops might influence the logistics attractiveness of the port. 


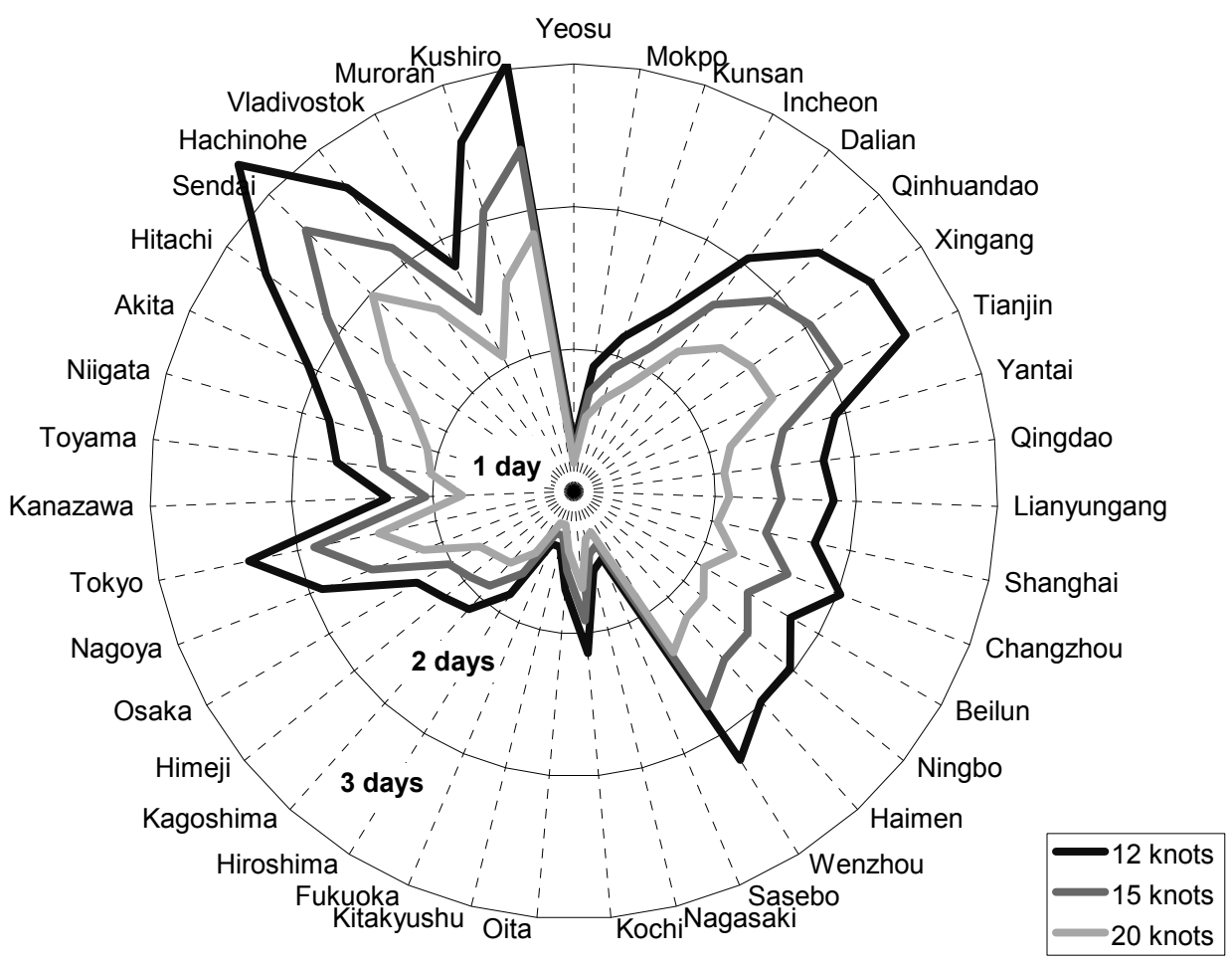

Source: Own analysis based on distance tables from dataloy.com

Figure 7. Sailing times (direct service) from Busan to selected ports at different speeds

As was said before, only if port and hinterland characteristics give companies the luxury to choose between port and hinterland areas for locating logistics activities the product and firm characteristics will become decisive. If one takes into account the enabling or disabling role of port and hinterland characteristics in terms of the locational decision of logistics activities, most of the product and firm characteristics, however, will follow traditional frameworks proposed earlier in literature (e.g. TNO Inro, 2004; Kuipers and Eenhuizen, 2004). The reason why respondents in Section 4.3 found products with high delivery frequency most attractive for the port lies in the role that companies in Busan want to play in offering logistics activities for transshipment cargo, for which indeed a fairly high delivery frequency can be offered as a result of the many deep- and short-sea connections. For the captive hinterland, on the other hand, delivery frequency is not such an issue since the opposite end of the South-Korean peninsula can be reached by truck within a day. Similar arguments hold for products with a high value per cubic meter or country-specific product and packaging requirements. Regarding the latter, for instance, a port as logistics hub is able to offer value-added logistics such as product customization. 
Considering characteristics of firms and logistics structures, it still holds that firms with a global (and to a lesser extent regional) focus will reap more benefits from often eccentrically located port areas than firms with a rather local logistics focus. Similar arguments are valid for integrated logistics networks as opposed to stand-alone facilities, while firms with many importing and exporting activities will evidently favor port areas over hinterland regions as well. The preference of seaports for logistics structures with stronger focus on costs than service was another observation from Section 4.2, which at first sight seems contradictory to the preference of highfrequency goods for the port. One should not forget, however, that the Port of Busan is not a pure transshipment hub, but still has several millions of TEU in import and export cargo for the Korean market. According to the typology in Figure 5, for those goods the classical frameworks hold, so that indeed the port will be preferred when costs are important. This is especially true given the relative absence of strongly developed corridors for transportation of large quantities of cargo (cf. nearly $90 \%$ of the modal split is truck transportation). High uncertainties in customer demand as well as lead times, finally, will push firms as close to their customer base as possible, whether or not overseas.

\section{Conclusions}

Seaports are key constituents of many supply chains. Many ports have actively stimulated the development of logistics activities in port areas. This paper presented a generic framework on port logistics development and its interaction with hinterland regions. It was highlighted that earlier work on the topic offers valuable insights on the factors impacting the location of logistics activities in ports or the hinterland, but most of earlier work is focused on a specific port region, limiting the external validity or the potential for a generalization of the results.

This paper made an attempt to present a model for determining seaport-located logistics activities taking into account dissimilarities among ports. The framework is therefore applicable to a variety of seaport ranges worldwide. A first in a series of empirical applications focused on the port of Busan. In later papers also other ports will be considered and a more quantitative approach to analyze the survey results will be followed. The case of Busan has its merits as it clearly demonstrates the shortcomings of more traditional approaches that are valid in a context of gateway ports sharing a large contestable hinterland connected to the seaports via well-developed multimodal corridors. The framework presented in the last sections of the paper explicitly adds port and hinterland characteristics to the list of factors decisive in the choice of the location of logistics activities.

\section{Acknowledgement}

We gratefully acknowledge financial support from the FWO (Research Foundation Flanders) through the first author's fellowship. 


\section{Appendix. Port characteristics}

\begin{tabular}{|c|c|}
\hline & Port characteristics \\
\hline S1 & Accessible to large container vessels ( $>5000$ TEU) \\
\hline $\mathrm{S} 2$ & Government policy regarding ports and sound institutional environment in ports \\
\hline S3 & Geographical location near main shipping route(s) \\
\hline S4 & Good availability and high quality of modern port infrastructure (quays, locks, ...) \\
\hline S5 & $\begin{array}{l}\text { Good availability and high quality of modern port superstructure (cranes, warehouses, stacking } \\
\text { equipment, etc..) }\end{array}$ \\
\hline S6 & High level of technological innovation in port (integration of ICT systems, automation, ...) \\
\hline S7 & Labor availability in port area \\
\hline S8 & Less stringent labor regulations in port area \\
\hline S9 & Low labor costs in port area \\
\hline S10 & Efficient customs procedures in port area \\
\hline S11 & Presence of Free Trade Zones in the port area \\
\hline S12 & Presence of Free Trade Zones in the port's hinterland \\
\hline S13 & Number and frequency of port-hinterland connections (by road, rail, barge, pipeline) \\
\hline S14 & Quality of port-hinterland connections (e.g. congestion-free, reliable, etc..) \\
\hline S15 & Port location close to major consumption areas \\
\hline S16 & Proximity to other seaports (i.e. more hinterland overlap) \\
\hline S17 & Proximity to production and consumption centers in the hinterland \\
\hline S18 & Port logistics zones located close to container terminals and other infrastructure \\
\hline S19 & Good reputation/image of port \\
\hline S20 & Large port throughput / large scale of the port \\
\hline S21 & Low total factor costs (distribution, warehousing and personnel) \\
\hline S22 & High reliability of port operations (e.g. absence of strikes, ...) \\
\hline S23 & Port mainly focused on stevedoring activities (loading/unloading, temporary storage) \\
\hline S24 & Port strongly involved in logistics activities (e.g. Value-Added Logistics and Services) \\
\hline S25 & Multicultural character of port society \\
\hline S26 & Language knowledge of port society \\
\hline S27 & Operational skills of port society \\
\hline S28 & Market power of shippers \\
\hline S29 & Market power of shipping lines \\
\hline S30 & Market power of port industry \\
\hline S31 & Port located in more economically integrated region (e.g. European Union) \\
\hline
\end{tabular}




\section{References}

Bird, J. 1980. Seaports and Seaport Terminals. London: Hutchinson University Library.

Buck Consultants International. 1996. Seaports and Their Hinterland. Nijmegen: Buck Consultants International.

Derveaux, H. 2004. Port logistics: the Antwerp case. in Proceedings of the First International Conference on Logistics Strategy for Ports, eds. S. Licheng and T. Notteboom. 394407. Dalian: Dalian Maritime University Press.

Ferrari, C., Parola, F. and E. Morchio. 2006. Southern European Ports and the Spatial Distribution of EDCs. Maritime Economics and Logistics 8: 60-81.

Frankel, E.G. 1987. Port Planning and Development. New York: John Wiley \& Sons.

Kuipers, B. 1999. Liège, Tongeren, Genk or the Maasvlakte: What's the Difference? Spatial Behaviour of Europan Distribution Centres. in Vervoerslogistieke werkdagen 1999, eds. R.H.J. Rodenburg and A.L. Kruse, Delft: Connekt.

Kuipers, B. and J. Eenhuizen. 2004. A Framework for the Analysis of Seaport-based Logistics Parks. in Proceedings of the First International Conference on Logistics Strategy for Ports, eds. S. Licheng and T. Notteboom. 151-171. Dalian: Dalian Maritime University Press.

Notteboom, T. and W. Winkelmans. 2004. FR-WP1: Overall Market Dynamics and Their Influence on the Port Sector. in Factual Report on the European Port Sector. European Sea Ports Organisation. 4-60. Brussels: ESPO.

Notteboom, T. and J-P. Rodrigue. 2005. Port Regionalization: towards a New Phase in Port Development. Maritime Policy and Management 32. no.3: 297-313.

Prologis-CapGemini. 2006. Moving Freight Today - How Shippers are Creating Greater Capacity, Reliability and Rate Stability. Prologis Supply Chain Review.

TNO Inro. 2004. EDC's op de vlakte houden! Delft: TNO Inro.

United Nations. 2002. Commercial Development of Regional Ports as Logistics Centres. Research Report of the Economic and Social Commission for Asia and the Pacific. New York.

United Nations. 2005. Free Trade Zone and Port Hinterland Development. Research Report of the Economic and Social Commission for Asia and the Pacific. New York.

Valentine, V.F. and R. Gray. 2000. The Measurement of Port Efficiency using Data Envelopment Analysis. World Conference on Transport Research. Special Interest Group-2.

http:/www.informare.it/news/forum/2000/sig2/valentinees.asp

Van Klink, H.A. and G.C. Van den Berg. 1998. Gateways and Intermodalism. Journal of Transport Geography. 6. no.1: 1-9.

Woxenius, J., Rosso, V. and K. Lumsden. 2004. The Dry Port Concept - Connecting Seaports with Their Hinterland by Rail. In Proceedings of the First International Conference on Logistics Strategy for Ports, eds. S. Licheng and T. Notteboom. 305-319. Dalian: Dalian Maritime University Press. 